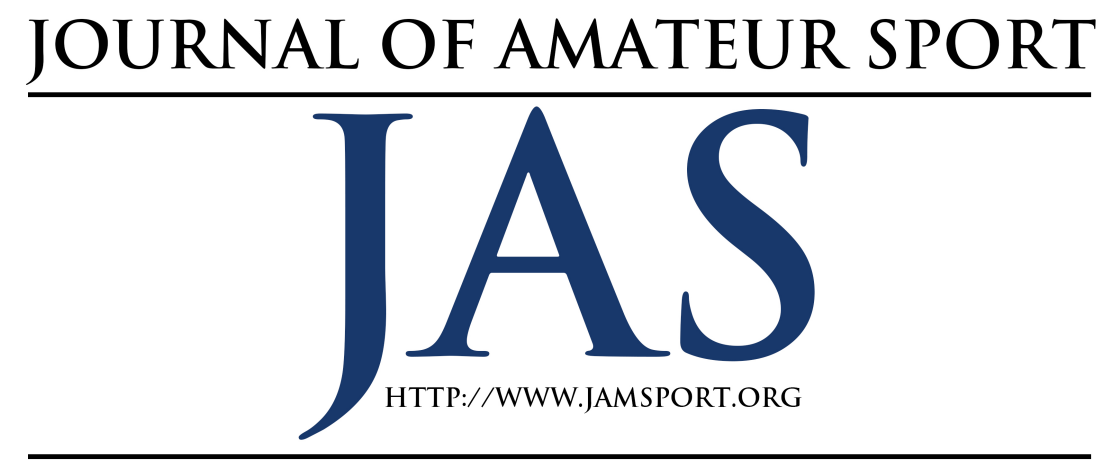

\title{
Do Psychosocial Services Make the Starting Lineup? Providing Services to Student-Athletes
}

\author{
Matt Moore \\ Ball State University
}

\begin{abstract}
Participation in college athletics comes with inherent risks. Many of these risks relate to the psychosocial well-being of athletes. This study examined the availability of services that treat psychosocial needs. A web-based survey was used to gather information from both athletic directors $(N=132)$ and athletes $(N=349)$. The researcher used descriptive and multivariate tests to analyze the data and found both athletic directors and athletes found psychosocial services to be less available than academic and athletic services. Additionally, NCAA division level impacted the degree of service availability. More must be done to ensure the psychosocial wellbeing of college athletes. This includes exploring ideas for having services more readily available.
\end{abstract}

A $t$ the end of the 2014 fiscal year, the National Collegiate Athletic Association (NCAA) had an $\$ 80.5$ million surplus from the $\$ 989$ million it pulled in through various means (USA Today, 2014). For the NCAA, March Madness is its most profitable enterprise bringing in roughly $\$ 900$ million in revenue (Berr, 2015). Revenue earned through March Madness and other events goes straight back to athletic programs that equip student-athletes to exceed on the field, in the classroom, and in life (NCAA, 2016b). The question becomes whether or not these NCAA programs are truly supporting the academic, athletic, and psychosocial wellbeing of student-athletes - the studentathletes responsible for generating NCAA revenues.

In order to support student-athlete success both in and away from competition, programs must be available to assist athletes with ongoing needs (Gill, 2008). This research explored the opinions of student- 
athletes and athletic directors as it relates to the availability of academic, athletic and psychosocial support services. This study looked for overall opinions, but also sought to examine whether or not there is a difference in available support services across NCAA Division levels (I, II, and III). In 2014, the NCAA allocated roughly $\$ 547$ million to Division I conferences and schools, which is twice that allocated to Division II and III programs (USA Today, 2014). Therefore, Division I programs might have the resources to make services more readily available.

Another primary objective of this study is to explore the availability of services that address psychosocial risks. This research refers to a psychosocial risk as any challenge to the psychological or social development of a student-athlete that is a result of his or her participation in an athletic environment (Anderson, Petrie, \& Neumann, 2011; Beauchemin, 2014; Watson \& Kissinger, 2007). This is of importance as the NCAA named mental health as the number one health concern facing student-athletes (NCAA, 2013b). Mental health risks can include depression, suicide, substance abuse, alcohol abuse, and disordered eating, amongst others (NCAA, 2013b). For example, research shows that up to $33 \%$ of student-athletes experience symptoms of depression (Cox, 2015; Wolanin, Hong, Marks, Panchoo, \& Gross, 2015). With such a high prevalence rate, available services are needed to promote student-athlete wellbeing and resilience.
Currently, very little is known about service availability, especially as it relates to psychosocial services. In a recent study, $25.7 \%$ of student-athletes did not know how or where to access mental health treatment at their university (Cox, 2015). A report from the NCAA (2015), found that most athletic departments do not employ full-time or even part-time practitioners specializing in mental health. Instead, these athletic departments depend on campus resources such as counseling centers (NCAA, 2015).

By understanding current perceptions of service availability, this research can shed light on whether or not the NCAA and athletic departments are doing what is necessary to help student-athletes succeed and properly using the revenues gained by student-athletes. Making services available is one of the first steps towards ensuring student-athlete safety and well-being. The information gleaned from this study could help the NCAA and athletic programs recognize existing strengths and address current limitations for meeting the unique needs of student-athletes. This research can also provide practitioners with insight about the perceptions of student-athletes and encourage them to think critically on how they can make their presence more felt. Lastly, hearing directly from student-athletes will allow their voice to be heard and allow researchers to advocate for the advancement of their well-being. 


\section{Literature Review}

The Current Approach to StudentAthlete Support Services

The NCAA (2016b) does have recommendations for promoting the success of a student-athlete on the field, in the classroom, and in life. The NCAA Sport Science Institute promotes these recommendations. These recommendations call for athletic departments across the country to provide student-athletes access to athletic training, sports medicine, academic advisors, tutoring services/study tables, and career development.

The NCAA (2013b) also has recommendations for assessing the mental health concerns of student-athletes (e.g., depression, suicide, alcohol abuse, substance abuse, and disordered eating, amongst others). These recommendations stem from the work of the NCAA Mental Health Task Force, a task force comprised of mental health professionals across the country. Task Force recommendations include referring student-athletes for psychosocial evaluation and care, addressing psychosocial risks during pre-participation examinations, establishing standards for approaching student-athletes with a psychosocial risk, scheduling routine evaluations to assess a student-athlete's total well-being, establishing standards for submitting outside referrals for severe cases, and educating student-athletes about potential psychosocial risks, amongst other recommendations (NCAA, 2013a).
To implement current recommendations, the NCAA allows each school's athletic department to determine how best to meet the academic, athletic, and psychosocial needs of their student-athletes. In other words, there are 1,092 NCAA affiliated colleges and universities providing support services in potentially different ways. This research will give a glimpse into the equality of this approach and whether or not athletic departments are ensuring that academic, athletic, and psychosocial support services are all readily available to studentathletes. The researcher is hypothesizing that academic and athletic services will be more readily available, despite the fact that mental health concerns are the number one problem facing student-athletes. The primary reason for this hypothesis is the ongoing stigma associated with mental health. Student-athletes, coaches, and staff tend to minimize mental disorders as it is counter-productive to traditional sport culture that tells us athletes are supposed to be mentally tough (Baumann, 2016; Carr \& Davidson, 2015; Corrigan, Druss, \& Perlick, 2014). Believing in traditional sport culture is dangerous as reality tells us that psychosocial risks are fast-growing in the world of college athletics.

\section{Psychosocial Risks of Student-Athletes}

Research on the psychosocial risks of student-athletes often considers multiple confounding variables. Variables include, but are not limited to, gender, ethnicity/race, competition level (Division I, 
II, and III), type of sport (team or individual), profile of sport (high profile or low profile), the college or university's religious affiliation, and affiliation as a historically black college or university (HBCU). The following sections explore how and why many of these variables impact student-athletes in relation to depression, suicide, alcohol use, illicit substance use, disordered eating, and general well-being. These sections also highlight the need for psychosocial services.

Depression and suicide. An estimated $33 \%$ (or as many as 148,500 ) of the 450,000 student-athletes self-identify as being depressed (Cox, 2015). Wolanin and colleagues (2016) found that $23 \%$ of these student-athletes meet clinically relevant levels of depressive symptoms. Overall, female student-athletes are almost two times more likely to experience sport-related depression than their male counterparts (Wolanin et al., 2015).

Miller and Hoffman (2009) found that approximately $5 \%$ of student-athletes contemplate suicide. Suicide is the fourth leading cause of death in student-athletes (Rao \& Hong, 2015). Some feel studentathletes are more likely to suffer from depression and attempt suicide because they cannot handle athletic pressure, believe their identity is only based on their athletic association, do not believe a helping professional would understand their unique situations, are struggling academically, and/or feel isolated from the overall campus population (DeFreese \& Smith,
2013; Miller \& Hoffman, 2009). Studentathletes suffering from depressive symptoms and suicidal ideation are also more likely to use alcohol and illicit substances as a coping mechanism (dual diagnosis) (Gill, 2008).

Little research is available on the association between a student-athlete's ethnicity/race and mental health risks. There is also little research available about the mental health risks faced by studentathletes at a HBCU versus other colleges and universities. Yet, what is available points directly to the isolation and discrimination that male, Black studentathletes face (Agyemang, Singer, \& DeLorme, 2010). In particular, male, Black student-athletes are more likely than male, White student-athletes to be viewed only as athletes and not as students, are more likely to be isolated from other members of the campus community, and are more likely to face academic discrimination by faculty members (Steinfeldt, Reed, \& Steinfeldt, 2010). For male, Black student-athletes, negotiating their racial and athletic identities is difficult because both roles are linked together in the minds of others, which certainly poses risks to a student-athlete's mental well-being (Hudson-Banks \& KohnWoods, 2007; Steinfeldt et al., 2010). Not to mention, for many male, Black studentathletes, they see athletics as their vehicle to self-realization and socioeconomic advancement (Edwards, 2000). Unfortunately, for most of these studentathletes, their dreams of becoming the next 
professional superstar will not come true.

This is detrimental to these student-athletes as many of them dedicated their entire college career to athletics, which meant they spent little time on their career and occupational development (Edwards, 2000).

Alcohol use. A recent report from the NCAA (2015), showed that $80.5 \%$ of student-athletes consumed alcohol each year. Over the past ten years, researchers have consistently shown that studentathletes are prone to episodes of binge drinking, with $40 \%$ to $52 \%$ of athletes reporting they have consumed more than five drinks in a night (Druckman, Gilli, Klar, \& Robison, 2015; Ford, 2007a; Yusko, Buckman, White, \& Pandina., 2008). Student-athletes participating in a team sport (e.g., basketball) versus an individual sport (e.g., wrestling) were more likely to engage in high risk alcohol consumption (Brenner \& Swanik, 2007). Student-athletes competing at the Division III level (83\%) were more likely to participate in risky behaviors involving the usage of alcohol than student-athletes at the Division II $(79 \%)$ or Division I $(78 \%)$ level (NCAA, $2013 \mathrm{c})$. Male $(80 \%)$ and female $(82 \%)$ student-athletes use alcohol at nearly an identical rate. However, male studentathletes are more likely to engage in episodes of binge drinking (NCAA, 2013c). White student-athletes also reported higher levels of alcohol consumption than athletes identifying a different race (Doumas \& Midgett, 2015).
The high prevalence rate of alcohol abuse among student-athletes is attributed to many factors. Studies indicate that student-athletes often drink as a way to socialize and impress their teammates (Wahesh, Milroy, Lewis, Orsini, \& Wyrick, 2013; Zamboanga, Rodriguez, \& Horton, 2008). Student-athletes also use alcohol as a sport-related coping mechanism (e.g., to overcome athletic pressure) or as a sportrelated positive reinforcement mechanism (e.g., as a tool to enhance athletic performance) (Wahesh et al., 2013). Other reasons for alcohol consumption among student-athletes include the use of alcohol as a tool to overcome academic stress and a student-athlete's belief that alcohol consumption will help him or her fit in with the overall campus population (Ford, 2007a).

Illicit substance abuse. In addition to concerns about alcohol consumption, student-athletes are also at risk of abusing illicit substances. The NCAA (2013) found that $22 \%$ of student-athletes use marijuana. Male student-athletes are at a greater risk of marijuana use $(25 \%)$ than female studentathletes (17\%) (NCAA, 2013). Division III student-athletes are more likely to use marijuana (29\%) as compared to Division II $(20 \%)$ and Division I (16\%) student-athletes (NCAA, 2013).

Yusko and colleagues (2008) found that student-athletes also abuse banned performance enhancers at a rate of $6 \%$. This is similar to results reported by the NCAA (2013), which was 4.6\%. As was the case 
with marijuana use, male student-athletes and student-athletes competing at the Division III level were more likely to disclose use (NCAA, 2013). Male studentathletes who use performance enhancing drugs are also more likely to abuse alcohol (Buckman, Farris, \& Yusko, 2013;

Buckman, Yusko, Farris, White, \& Pandina, 2011; Buckman, Yusko, White, \& Pandina, 2009).

Ford (2007b) found that studentathletes participating in team sports were more likely to use illicit substances than student-athletes competing in individual sports. Student-athletes with strong religious affiliations were less likely to use substances as spirituality was a factor in the hesitation against doping behavior (Zenic, Stipic, \& Sekulic, 2013).

Researchers attribute substance use among student-athletes to many factors. Student-athletes use illicit substances for some of the following reasons (1) to improve athletic performance, (2) to treat sport-related injuries, (3) for social and personal reasons, (4) as an energy boost, (5) to suppress appetite for weight loss purposes, (6) to manage sport-related stress, and (7) to deal with the general stress of college life (Green, 2001). Student-athletes also use drugs to increase their feelings of belongingness with the overall campus population (Williams et al., 2008).

Disordered Eating. The likelihood of a student-athlete developing disordered eating symptoms varies based on gender. As a standard rule, female students, both athletes and non-athletes, face internal and external pressures to remain thin (Greenleaf, Petrie, Carter, \& Reel, 2009). Internal and external pressures might include negative mood states, low selfesteem, desire for weight control, involvement in a hurtful relationship outside of athletics, and perfectionism (ArthurCameselle \& Quatromoni, 2011). Findings on whether athletic involvement places female student-athletes at greater risk of developing disordered eating symptoms are inconsistent.

On one hand, researchers correlate a female's participation in athletics with heightened concerns about weight and the promotion of pathogenic eating behaviors. Greenleaf and colleagues (2009) found that $19 \%$ of female student-athletes showed partial symptoms of disordered eating. Conversely, other studies found that a female's participation in college sports was a protective factor to the development of disordered eating. Wollenberg, Shriver, and Gates (2015) found that $6.6 \%$ of female student-athletes showed symptoms of disordered eating. McLester, Hardin, and Hoppe (2014) found that $8 \%$ of female student-athletes were susceptible to disordered eating symptoms. However, this study found that $10 \%$ of female studentathletes had low self-esteem and $12 \%$ of female student-athletes were dissatisfied with their current body image.

While study results vary, research shows that female student-athletes struggle with disordered eating much like other female 
college students. However, in addition to the internal and external pressures discussed above, female student-athletes are also likely to develop disordered eating patterns to handle circumstances unique to athletic participation. Such circumstances might include modeling the behaviors of teammates, enhancing sport performance, and addressing negative comments of a coach, teammate, opposing players, and fans (Arthur-Cameselle \& Quatromoni, 2011 Wollenberg et al., 2015).

Male student-athletes are less likely to develop disordered eating symptoms than female student-athletes. According to Chatterton and Petrie (2013), less than 2\% of male student-athletes met clinical criteria for disordered eating. However, certain male student-athletes are at a high risk of disordered eating. College wrestlers as compared to other male student-athletes are more than twice as likely to experience disordered eating (Bratland-Sanda \& Sundgot-Borgen, 2013; Chapman \& Woodman, 2016).

Overall, male student-athletes were most likely to develop disordered eating patterns to address coach/teammate pressure, to lose or gain weight for weigh-in, to enhance sport performance, or because of their internal association that more fit student-athletes receive more playing time (Baum, 2006).

Outside of gender specific findings, research shows that disordered eating is more common amongst male and female student-athletes who participate in a sport where body weight is emphasized (e.g., cheerleading, distance running, and wrestling) (Baum, 2006). Furthermore, disordered eating is less common in sports that use referees as opposed to sports that use judges to gauge competition (Baum, 2006).

\section{Importance of this Study}

Knowing the rates at which studentathletes experience psychosocial risks, it becomes clear that the NCAA and athletic departments must provide support services to assess and intervene when studentathletes disclose their needs. This study provides one of the only examinations of the current availability of these psychosocial services. Recognizing whether or not services are available will give insight into the role the NCAA and athletic departments play in properly utilizing the revenues generated by student-athletes.

While this study looked at the overall availability of services across all NCAA division levels, the researcher also explored differences amongst division levels. This is important knowing that Division I athletic departments receive nearly twice the budget for support services as Division II and III programs. However, research identifies that student-athletes at Division II and III programs are more likely to experience psychosocial challenges than Division I student-athletes.

The findings from this study will help the NCAA and athletic departments explore the job they are doing providing services 
and/or promoting services. From a practice perspective, these findings could provide the eye-opener that the NCAA and athletic departments need to take the next step in advocating for student-athlete well-being. The more available services are the greater likelihood that college sports will not be harmful to the life aspiration of a studentathlete (Chatzisarantis \& Hagger, 2007). The psychosocial challenges impacting studentathletes are serious. Sadly, some of these students-athletes are leaving with more than a college degree - they are leaving with psychosocial risks that can have a long-term impact on their adulthood.

\section{Methods \\ Research Questions}

Knowing that athletic directors have a large voice in how support services are structured, this study drew comparison between athletic directors' perceptions and the perceptions of student-athletes as it related to the availability of athletic, academic, and psychosocial services.

The two research questions for this study focused on the availability of current support services. First, are there significant differences between a college athletic director's perception of the availability of athletic, academic, and psychosocial services based on their NCAA division membership? Second, are there significant differences between a student-athlete's perception of the availability of athletic, academic, and psychosocial services based on their NCAA division membership?

\section{Research Design}

For this exploratory study, the researcher used a cross-sectional, web-based survey design to collect information from athletic directors and student-athletes at NCAA affiliated colleges or universities.

To determine the desired sample size, the researcher began by selecting the statistical tests necessary to answer the research questions. The researcher used a Multivariate Analysis of Variance (MANOVA) for answering the research questions. This researcher used a statistical power of 0.80 and a medium effect size. With the lack of existing research to build a theoretical framework, the researcher used a medium as opposed to small or large effect size. The researcher used confidence intervals of 0.05 , which were liberal rather than accurate estimates. Considering these factors, the desired sample size for this study was a minimum of 98 athletic directors and 249 student-athletes (Faul, Erdfelder, Lang, \& Buchner, 2007). The final sample included 132 athletic directors and 349 athletes. With the final sample size, the statistical power for each research question exceeded 0.8 (Faul et al., 2007).

In order to obtain the desired number of responses from athletic directors and student-athletes, the researcher randomly selected 474 colleges or universities. The researcher predicted that only $10-15 \%$ of athletic directors would respond to the webbased survey. This anticipated response rate is consistent with many studies using webbased surveys (Hoonakker \& Carayon, 
2009; Munoz-Leiva, Sanchez-Fernandez, Montoro-Rios, \& Ibanez-Zapata, 2010). It was difficult to anticipate the number of student-athlete responses for this study. First, multiple student-athletes could respond from each college or university. Second, it was unknown to the researcher how many student-athletes would receive a copy of the survey since athletic directors were responsible for asking their athletes to participate.

The researcher used publicly available and complete lists of colleges and universities from the NCAA (2014) to conduct a proportionate stratified random sampling strategy. The researcher used division membership to identify three strata (Division I, II, and III). Each college or university belongs to only one division level. Nationwide, there are 346 Division I programs (32\%), 307 Division II programs (28\%), and 439 Division III programs (40\%) (NCAA, 2012). The researcher used a table of random numbers, in accordance with the desired sample size, to select 146 Division I programs, 138 Division II programs, and 190 Division III programs to participate in the study.

Once the researcher used stratified random sampling techniques to identify 474 colleges or universities, the researcher used the school's website to obtain the contact information (name and email address) for the athletic director. When contact information was not accurate or unavailable for an athletic director, the researcher contacted the college or university personally to obtain updated information.

Athletic directors completed one version of a web-based survey for their college or university as they are responsible for overseeing all aspects of college athletics. The researcher asked the athletic director to pass along the link for a webbased survey, a cover letter, and a study information sheet to his or her studentathletes for completion. To avoid potential selection bias, the researcher asked the athletic director to send the survey to all student-athletes competing at their university.

\section{Study Participants}

Athletic directors. Of the 474 athletic directors contacted, 132 participated in the study (28\% response rate).

The researcher collected information about age, gender, race, education level, years in current position, years in administration, and NCAA division membership for each athletic director (see Table 1). The age range for this sample was 27-70 years $(M=49.90)$. Male athletic directors accounted for $69 \%$ of the total sample. A majority of the athletic directors identified as White (94\%). The largest percentage of athletic directors had a Master degree $(68 \%)$. Athletic directors ranged in their time at their current position from 0 35 years $(M=8.32$, Median $=5)$. The average length of time spent in athletic administration was 22.43 years (Median $=$ 23), ranging from 1-41 years. The largest 
percentage of athletic directors worked at the Division II level (36\%).

The researcher also gathered basic information about each college or university, which included enrollment size, religious affiliation, and whether there was an affiliation as a HBCU. Enrollment size ranged from $570-30,000$ students $(M=$ 6,580, Median =2,624). Approximately $59 \%$ of respondents worked at a college or university with a religious affiliation. The most common religious affiliations were Methodist (11\%) and Catholic (10\%). Five $(4 \%)$ of the athletic directors worked for a HBCU.

Student-athletes. The researcher collected information about the age, gender, race, class standing, number of years playing college athletics, sport played, NCAA division membership, and profile of sport for the 349 student-athletes that participated in the study (see Table 2). The age range for this sample was $18-25$ years $(M=19.44)$. Female student-athletes accounted for 55\% of the total sample. A majority of the student-athletes identified as White (74\%). Thirty percent of the respondents were sophomores in college. Approximately 45\% of student-athletes were in their first year of competing in college athletics. The largest percentage of student-athletes competed at the Division III level (39\%). Over half of the student-athletes $(56 \%)$ identified their sport to be low profile. Student-athletes from this sample competed in 18 different sports. The most popular sports played were soccer, basketball, football, and softball.

\section{Measures/Instruments}

Development of survey

questionnaire. The researcher was not able to locate previously validated surveys for this study. Thus, the researcher developed a new survey questionnaire for athletic directors and for student-athletes. The researcher provided the draft survey to a panel of five experts in the field of college athletics for their review and feedback of the survey's readability, content, length, and face validity. The researcher also tested for internal consistency of the questionnaires by using Cronbach's $\alpha$. For the athletic director questionnaire there was a Cronbach's $\alpha$ of 0.88 . The student-athlete questionnaire had a Cronbach's $\alpha$ of 0.92 . Both surveys consisted of nine questions about service availability.

Athletic director survey. Questions about service availability were related to nine support services, which were further broken down into three distinct categories. First, athletic services included athletic training and medical services. Second, academic services included academic advising, career development, and tutoring services. Third, psychosocial services included mental health services, substance abuse services, alcohol addiction services, and suicide prevention. Regarding service availability, athletic directors responded to how available each of the nine support services are to their student-athletes on a 
nine-point Likert scale (" $0=$ Never" to "8 = All the Time"). The researcher elected for a nine-point Likert scale so participants would have enough points of discrimination and variance for their thoughts.

Student-athlete survey. Questions about service availability included the same list of services used in the athletic director survey. Regarding service availability, student-athletes were asked when needed, how available are each of the nine support services on their campus (" $0=$ Never" to " 8 $=$ All the Time").

Demographics. All study participants answered questions about their age (years), gender, ethnicity, and NCAA division membership. Athletic directors identified the time spent in their current position (years), time spent working in college athletics (years), and their highest level of education. The researcher also asked athletic directors to identify their college or university enrollment size, religious affiliation (if applicable), and whether they worked for a HBCU. Student-athletes had to identify the sport(s) they played, the profile of their sport (high profile referred to sports with geographic importance, strong fan support, increased media attention and/or higher rates of athletic department funding), class standing, and the number of years they have competed in college athletics.

\section{Data Analysis}

There was one independent variable in this study - NCAA division membership (I,
II, or III). This variable was categorical.

There were multiple dependent variables for this study as the researcher created composite (sum) scores. The researcher calculated three composite scores for each type of available service: athletic, academic and psychosocial services.

The researcher used descriptive statistics to provide details about the sample and an overview of the survey results. The descriptive statistics also allowed the researcher to compare athletic directors' perceptions to student-athletes' perceptions in regards to service availability. The researcher used SPSS 21.0 for Windows to complete these statistical tests.

Each research question used a MANOVA. These tests allowed the researcher to examine the mean differences between levels of the independent variable(s) on three dependent variables related to each question. The use of MANOVAs not only protected the inflation of type I error, but also allowed the researcher to examine group differences on each dependent variable, as well as group differences on the combined construct (Field, 2009).

\section{Descriptive Statistics}

Availability of support services. The researcher asked athletic directors and student-athletes to rate the current level of availability of athletic, academic, and psychosocial services on their campus (see Table 3). Athletic directors and student- 
athletes both identified athletic and academic services to be the most readily available services on their campus. The services that athletic directors and studentathletes perceived as being the least available were the psychosocial services. Overall, student-athletes (overall mean $=$ 5.38) viewed all services as being less available than athletic directors (overall mean $=6.24)$. The results of a $t$-test showed a significant difference between these two overall means $(p=0.002)$. This was especially true for psychosocial services as student-athletes (overall mean $=4.23$ ) viewed these services as being less available than athletic directors (overall mean $=5.40$ ).

\section{Statistical Assumptions}

MANOVA. The researcher used a MANOVA to answer the research questions. Prior to analysis, data for all research questions were evaluated to ensure that the assumptions for this multivariate test were fulfilled. All assumptions of the MANOVA were satisfied.

\section{Result of the MANOVA}

\section{Main effect - NCAA division} membership (athletic director). The results of the MANOVA showed an overall significant difference between NCAA division membership and a college athletic director's perception of the current availability of athletic, academic, and psychosocial services (Pillai's Trace $=0.19$, $\left.F_{(2,129)}=4.37, p<0.001\right)$. Division level accounted for $10 \%$ of the variance in an athletic director's perceptions of service availability $\left(\mathbf{\eta}^{2=} 0.10\right)$.

The results of the post hoc betweensubjects effects indicated that athletic directors differed significantly based on their NCAA division level in their perception of how available psychosocial services are on their campus $\left(F_{(2,129)}=6.08\right.$, $\left.p=0.003, \mathrm{CI}_{95}=(24.28,26.62), \mathbf{\eta}^{2=} 0.09\right)$. Division III $(M=27.94)$ athletic directors perceived significantly more availability of psychosocial services than Division I $(M=$ 22.79) athletic directors (See Table 4). There were no significant differences between NCAA division level and athletic directors' perception of availability for athletic $\left(F_{(2,129)}\right.$ $\left.=0.33, p>0.05, \eta^{2}=0.01\right)$ and academic services $\left(F_{(2,129)}=1.15, p>0.05, \eta^{2}=0.02\right)$.

\section{Main effect - NCAA division} membership (student-athlete). The results of the MANOVA showed an overall significant difference between NCAA division membership and a student-athlete's perception of the current availability of athletic, academic, and psychosocial services (Pillai's Trace $=0.13, F_{(2,346)}=7.89, p<$ 0.001). Division level accounted for $7 \%$ of the variance in a student-athlete's perception of service availability $\left(\eta^{2}=0.07\right)$.

The results of the post hoc betweensubjects effects indicated that studentathletes differed significantly based on their NCAA division level in their perception of how available athletic services are on their campus $\left(F_{(2,346)}=12.27, p<0.001, \mathrm{CI}_{95}=\right.$ $\left.(14.12,15.28), \eta^{2}=0.07\right)$. Division $\mathrm{I}(M=$ 
15.37) and Division II ( $M=15.18)$ studentathletes perceived significantly more availability of athletic services than Division III $(M=14.60)$ student-athletes.

Student-athletes also differed on their perception of availability for academic services $\left(F_{(2,346)}=7.35, p=0.01, \mathrm{CI}_{95}=\right.$ (21.23, 23.03), $\left.\mathrm{\eta}^{2=} 0.04\right)$. Division $\mathrm{I}(M=$ 23.39) student-athletes perceived significantly more availability of academic services than Division III $(M=20.88)$ student-athletes.

Student-athletes' perceptions on the availability of psychosocial services differed by division level too $\left(F_{(2,346)}=11.23, p<\right.$ 0.001, $\left.\mathrm{CI}_{95}=(9.54,12.09), \mathrm{\eta}^{2}=0.06\right)$. Division I $(M=12.75)$ and Division II $(M$ $=11.19)$ student-athletes perceived significantly more availability of psychosocial services than Division III student-athletes $(M=8.49)$. See Table 5 for a complete breakdown of the MANOVA results.

\section{Discussion}

\section{Significant Findings}

Division I and Division II studentathletes perceived athletic services to be more readily available at their colleges or universities than Division III studentathletes. Division I and Division II programs place a larger emphasis on athletics by offering athletic scholarships, spending more money on athletic programming, and finding more ways to produce revenue through athletic functions (Foster, 2014; Gill, 2014; USA Today,
2014). Knowing that these programs place a larger emphasis on competition and generate increased revenue, it is logical they receive a larger share of NCAA revenues and can spend more on services such as athletic training and sports medicine (USA Today, 2014).

Student-athletes also perceived that Division I programs had significantly more availability of academic services than Division III programs. Division I programs are more likely to provide student-athletes with dedicated academic advisors, specialized orientation assistance, built-in study tables, and hired tutors (Armstrong \& Oomen-Early, 2009). Offering these services is in direct relation with the NCAA's (2016a) Academic Progress Rate (APR) and Graduation Success Rate (GSR) standards for Division I programs. To ensure Division I programs are in compliance with these standards, the NCAA provides more funds in academic support services. The academic success of Division II and III programs are not monitored with APR and GSR scores.

Descriptive statistics on the availability of support services also presented significant findings. First, student-athletes viewed psychosocial services as being less available on their campus than did athletic directors at each division level. Second, both athletic directors and college athletes at all division levels indicated that psychosocial services were less available than both athletic and academic services. Specifically, Division III athletic directors perceived 
psychosocial services to be significantly more available than Division I programs. Student-athletes shared the opposite viewpoint, in that Division I and Division II student-athletes perceived psychosocial services to be more readily available than Division III student-athletes.

\section{Equality of Psychosocial Services}

It is alarming to see that both studentathletes and athletic directors believed psychosocial services are not as readily available on their campus as athletic and academic services, especially knowing that mental health is the largest problem facing the student-athlete population (NCAA, 2013b). One major concern is the number of students that might not receive services if help is not available to them (Cox, 2015).

Using principles of distributive justice (Mahoney, Hums, \& Riemer, 2005), it is evident that more must be done to address the lack of resources available for mental health counseling, alcohol and addiction services, services for disordered eating, and suicide prevention. The level of psychosocial services available to studentathletes should not be linked to revenue production, but should be based on the equality of promoting the short- and longterm health of student-athletes (Patrick, Mahoney, \& Petrosko, 2008). Psychosocial services should also be equal across division levels. As evident by existing research, rates of mental health disorders are similar across membership (NCAA, 2013c). Having these services readily available might also dispel current stigmas that athletes should be mentally tough - not mentally ill (Baumann, 2016; Carr \& Davidson, 2015).

\section{Study Limitations}

This research study had limitations that might have impacted the results. First, despite an attempt to randomly select an initial study sample, the response rates made the final sample more of an availability sample. This causes concerns with the generalizability of the findings. Second, the measurement tools used for this research were constructed specifically for this study. While the researcher was able to check for face and content validity and internal consistency reliability, additional information about the reliability and validity of the tools remains unknown. Third, the findings in this study presented similar challenges as previous research, with only having small effect sizes (Armstrong \& Oomen-Early, 2009; Watson \& Kissinger, 2007; Yusko et al., 2008). Fourth, this study relied on self-reported data. Thus, there is no way to independently verify participant responses.

\section{Directions for Future Research}

In order to promote the availability of psychosocial services, future research should examine how athletic departments currently distribute their funds from the NCAA. Research should also evaluate the existing service structure to further explore service accessibility, service effectiveness, and barriers to receiving services. 
From the viewpoint of a practitioner, future research should evaluate existing and new practice models to determine what evidence-based approaches are best suited for assessing and intervening when a student-athlete is experiencing psychosocial challenges. This research should also explore interprofessional models to ensure that all academic, athletic, and psychosocial needs of student-athletes receive proper attention. Finally, future research should look at strategies to empower studentathletes to advocate for the services they need.

\section{Conclusion}

Sports come with inherent risks. While the current environment certainly does not turn a blind eye to student-athlete safety and well-being, there are areas where improvements might go a long way. While risks are engrained in athletics, these risks should not include such high percentages of depression, suicidal ideation, alcohol abuse, substance abuse, or disordered eating. If psychosocial services are not more readily available, what happens to the estimated 148,500 student-athletes suffering from depression (Cox, 2015), the 22,500 studentathletes contemplating suicide (Miller \& Hoffman, 2009), or the 99,000 studentathletes using marijuana (NCAA, 2013c)?

Research of this nature emphasizes the psychosocial need of athletes and encourages the NCAA, athletic departments, and practitioners to do more to promote the dignity and worth of 


\section{References}

Agyemang, K., Singer, J. N., \& DeLorme, J. (2010). An exploratory study of black male college athletes' perceptions on race and athlete activism. International Review for the Sociology of Sport, 45(4), 419-435.

Anderson, C. M., Petrie, T. A., \& Neumann, C. S. (2011). Psychosocial correlates of bulimic symptoms among NCAA division-I female collegiate gymnasts and swimmers/divers. Journal of Sport \& Exercise Psychology, 33(4), 483-505.

Armstrong, S., \& Oomen-Early, J. (2009).

Social connectedness, self-esteem, and depression symptomology among collegiate athletes verses nonathletes. Journal of American College Health, 57(5), 521-526.

Arthur-Cameselle, J. N., \& Quatromoni, P.

A. (2011). Factors related to the onset of eating disorders reported by female collegiate athletes. Sport Psychologist, 25(1),1-17.

Baum, A. (2006). Eating disorders in the male athlete. Sports Medicine, 36(1), 16.

Baumann, J. N. (2016). The stigma of mental health in athletes: Are mental toughness and mental health seen as contradictory in elite sports. British Journal of Sports Medicine, 50(3), 135-136.

Beauchemin, J. (2014). College studentathlete wellness: An integrative outreach model. College Student Journal, 48(2), 268-280.
Berr, J. (2015). March Madness: Follow the money. Retrieved from http://www.cbsnews.com/news/ma rch-madness-follow-the-money/.

Bratland-Sanda, S., \& Sundgot-Borgen, J. (2013). Eating disorders in athletes: Overview of prevalence, risk factors, and recommendations for prevention and treatment. European Journal of Sport Science, 13(5), 499-508.

Brenner, J., \& Swanik, K. (2007). High-risk drinking characteristics in collegiate athletes. Journal of American College Health, 56(3), 267-272.

Buckman, J. F., Farris, S. G., \& Yusko, D. A. (2013). A national study of substance use behaviors among NCAA male athletes who use banned performance enhancing substances. Drug and Alcohol Dependence, 131(1/2), 50-55.

Buckman, J. F., Yusko, D. A., Farris, S. G., White, H. R., \& Pandina, R. (2011). Risk of marijuana use in male and female college student athletes and nonathletes. Journal of Studies on Alcohol \& Drugs, 72(4), 586-591.

Buckman, J. F., Yusko, D. A., White, H. R., \& Pandina, R. (2009). Risk profile of male college athletes who use performance-enhancing substances. Journal of Studies on Alcohol \& Drugs, 70(6), 919-923.

Carr, C., \& Davidson, J. (2015). Mind, body, and sport: The psychologist perspective. Retrieved from http://www.ncaa.org/health-and- 
safety/sport-science-institute/mind-

body-and-sport-psychologist-

perspective.

Chapman, J., \& Woodman, T. (2016).

Disordered eating in male athletes: A meta-analysis. Journal of Sports Sciences, 34(2), 101-109.

Chatterton, J. M., \& Petrie, T. A. (2013).

Prevalence of disordered eating and pathogenic weight control behaviors among male collegiate athletes. Eating Disorders, 21(4), 328-341.

Chatzisarantis, N., \& Hagger, M. (2007).

The moral worth of sport reconsidered: Contributions of recreational sport and competitive sport to life aspirations and psychological well-being. Journal of Sports Science, 25(9), 1047-1056.

Corrigan, P. W., Druss, B. G., \& Perlick, D. A. (2014). The impact of mental illness stigma on seeking and participating in mental health care.

Psychological Science in the Public Interest, 15, 37-70.

Cox, C. (2015). Investigating the prevalence and risk-factors of depression symptoms among NCAA Division I collegiate atbletes. Retrieved from Proquest Digital Dissertations. (1592018)

DeFreese, J. D., \& Smith, A. L. (2013).

Teammate social support, burnout, and self-determined motivation in collegiate athletes. Psychology of Sport and Exercise, 14(2), 258-265.

Doumas, D. M., \& Midgett, A. (2015). Ethnic differences in drinking motives and alcohol use among college athletes. Journal of College Counseling, 18(2), 116-129.

Druckman, J., Gilli, M., Klar, S., \& Robison, J. (2015). Measuring drug and alcohol use among college studentathletes. Social Science Quarterly, 96 (2), 369-380.

Edwards, H. (2000). Crisis of black athletes on the eve of the $21^{\text {st }}$ century. Society, 37(3), 9-13.

Faul, F., Erdfelder, E., Lang, A. G., \& Buchner, A. (2007). G*Power 3: A flexible statistical power analysis program for the social, behavioral, and biomedical sciences. Behavior Research Methods, 39, 175-191.

Field, A. (2009). Discovering statistics using SPSS ( $3^{\text {rd }}$ ed.). Thousand Oaks, CA: Sage Publications.

Ford, J. (2007a). Alcohol use among college students: A comparison of athletes and nonathletes. Substance Use \& Misuse, 42(9), 1367-1377.

Ford, J. (2007b). Substance use among college athletes: A comparison based on sport/team affiliation. Journal of American College Health, 55(6), 367373.

Foster, K. (2014). Playbook: A career exploration program for student athletes at Ball State University. Ball State University, Muncie, IN.

Gill, E. L. (2014). Integrating collegiate sports into social work education. Journal of Social Work Education, 50(2), 305-321. 
Gill, E. L. (2008). Mental health in college athletics: It's time for social work to get in the game. Social Work, 53(1), 85-88.

Greenleaf, C., Petrie, T. A., Carter, J., \& Reel, J. J. (2009). Female collegiate athletes: Prevalence of eating disorders and disordered eating behaviors. Journal of American College Health, 57(5), 489-496.

Hoonakker, P., \& Carayon, P. (2009). Questionnaire survey nonresponse: A comparison of postal mail and internet surveys. Journal of HumanComputer Interaction, 25(5), 348-373.

Hudson-Banks, K., \& Kohn-Woods, L. P. (2007). The influence of racial identity profiles on the relationship between racial discrimination and depressive symptoms. Journal of Black Psychology, 33, 331-354.

Mahoney, D. F., Hums, M. A., \& Riemer, H. A. (2005). Bases for determining need: Perspective of intercollegiate athletic directors and athletic board chairs. Journal of Sport Management, 19, 170-192.

McLester, C. N., Hardin, R., \& Hoppe, S. (2014). Susceptibility to eating disorders among collegiate female student-athletes. Journal of Atbletic Training, 49(3), 406-410.

Miller, K. E., \& Hoffman, J. H. (2009). Mental well-being and sport-related identities in college students. Sociology of Sport Journal, 26(2), 335-356.
Munoz-Leiva, F., Sanchez-Fernandez, J., Montoro-Rios, F., \& Ibanez-Zapata, J. A. (2009). Improving the response rate and quality in web-based surveys through the personalization and frequency of reminder mailings. Quality \& Quantity, 44, 1037-1042. National Collegiate Athletic Association. (2016a). Academics. Retrieved from http://www.ncaa.org/about/whatwe-do/academics.

National Collegiate Athletic Association. (2013a). Health and safety. Retrieved from http://www.ncaa.org/wps/wcm/con nect/public/ncaa/health+and+safety National Collegiate Athletic Association. (2014). Members by division. Retrieved from http://www.ncaa.org/about/whowe-are/search-school.

National Collegiate Athletic Association. (2013b). NATA, NCAA and others announce mental health recommendation. Retrieved from http://www.ncaa.org/about/resourc es/media-center/news/nata-ncaaand-others-announce-mental-healthrecommendations.

National Collegiate Athletic Association. (2013c). NCAA national study of substance use habits of college studentathletes. Retrieved from http://www.ncaa.org/sites/default/f iles/Substance $\% 20$ Use $\% 20$ Final20Re port_FINAL.pdf. 
National Collegiate Athletic Association. (2015). Using NCAA data to understand student-athlete well-being. Retrieved from http://www.ncaa.org/research.

National Collegiate Athletic Association. (2016b). What is the NCAA? Retrieved from https://www.ncaa.org/about/resour ces/media-center/ncaa-101/whatncaa.

Patrick, I. S., Mahoney, D. F., \& Petrosko, J. M. (2008). Distributive justice in intercollegiate athletics: An examination of equality, revenue production, and need. Journal of Sport Management, 22(2), 165-183.

Rao, A., \& Hong, E. (2015). Understanding depression and suicide in college athletes: Emerging concepts and future directions. British Journal of Sports Medicine, 50(3), 136-137.

Steinfeldt, J. A., Reed, C., \& Steinfeldt, M. C. (2010). Racial and athletic identity of African American football players at historically black colleges and universities and predominantly white institutions. Journal of Black Psychology, 36(1), 3-24.

USA Today. (2014). NCAA finances.

Retrieved from http://www.usatoday.com/sports/co llege/schools/finances/.

Wahesh, E., Milroy, J. J., Lewis, T. F., Orsini, M. M., \& Wyrick, D. L. (2013). Hazardous drinking by firstyear college-athletes: The differential roles of drinking motives, alcohol consequences, and season status. Journal of Alcohol and Drug Education, 57(2), 66-84.

Watson, J., \& Kissinger, D. B. (2007). Athletic participation and wellness: Implications for counseling college student-athletes. Journal of College Counseling, 10(2),153-162.

Williams, R., Perko, M., Udan, S., Leeper, J., Belcher, D., \& Leaver-Dunn, D. (2008). Influences on alcohol use among NCAA athletes: Application of the social ecology model. American Journal of Health Studies, 23(3), 151159.

Wolanin, A., Hong, E., Marks, D., Panchoo, K., \& Gross, M. (2015). Prevalence of clinically elevated depressive symptoms in college athletes and differences by gender and sport. British Journal of Sports Medicine, 50(3), 167-171.

Wollenberg, G., Shriver, L. H., \& Gates, G. E. (2015). Comparison of disordered eating symptoms and emotion regulation difficulties between female college athletes and non-athletes. Eating Behaviors, 18, 1-6.

Yusko, D., Buckman, J., White, H., \& Pandina, R. (2008). Alcohol, tobacco, illicit drugs, and performance enhancers: A comparison of use by college student athletes and nonathletes. Journal of American College Health, 57(3), 281-290. 
Zamboanga, B. L., Rodriguez, L., \&

Horton, N. J. (2008). Athletic

involvement and its relevance to

hazardous alcohol use and drinking game participation in female college athletes: A preliminary investigation. Journal of American College Health, 56(6), 651-656.

Zenic, N., Stipic, M., \& Sekulic, D. (2013). Religiousness as a factor of hesitation against doping behavior in collegeage athletes. Journal of Religion and Health, 52(2), 386-396. 


\section{Tables}

Table 1

Athletic Director Demographics $(N=132)$

\begin{tabular}{|c|c|c|}
\hline Demographic Characteristic & $N$ & $\%$ \\
\hline Age $(M, S D)$ & $49.90(9.96)$ & \\
\hline $\begin{array}{l}\text { Years in Current Position }(M / \text { Median, } \\
S D)\end{array}$ & $8.32 / 5(7.99)$ & \\
\hline $\begin{array}{l}\text { Years in Administration }(M / \text { Median, } \\
S D)\end{array}$ & $22.43 / 23(10.12)$ & \\
\hline \multicolumn{3}{|l|}{ Race } \\
\hline White & 124 & $94 \%$ \\
\hline Black & 6 & $5 \%$ \\
\hline Multi-racial & 2 & $1 \%$ \\
\hline \multicolumn{3}{|l|}{ Education Level } \\
\hline Bachelor & 19 & $14 \%$ \\
\hline Master & 90 & $68 \%$ \\
\hline Doctorate & 21 & $16 \%$ \\
\hline No Four Year Degree & 2 & $2 \%$ \\
\hline \multicolumn{3}{|l|}{ NCAA Division Membership } \\
\hline Division I & 38 & $29 \%$ \\
\hline Division II & 48 & $36 \%$ \\
\hline Division III & 46 & $35 \%$ \\
\hline
\end{tabular}


Table 2

Student-Athlete Demographics $(N=349)$

\begin{tabular}{|c|c|c|}
\hline $\begin{array}{l}\text { Demographic } \\
\text { Characteristic }\end{array}$ & $N$ & $\%$ \\
\hline Age $(M, \mathrm{SD})$ & $19.44(1.26)$ & \\
\hline \multicolumn{3}{|l|}{ Gender } \\
\hline Male & 157 & $45 \%$ \\
\hline Female & 192 & $55 \%$ \\
\hline \multicolumn{3}{|l|}{ Race } \\
\hline White & 259 & $74 \%$ \\
\hline Black & 45 & $13 \%$ \\
\hline Multi-racial & 32 & $9 \%$ \\
\hline Asian & 7 & $2 \%$ \\
\hline American Indian & 5 & $1 \%$ \\
\hline Pacific Islander & 1 & $<1 \%$ \\
\hline \multicolumn{3}{|l|}{ Class Standing } \\
\hline Freshman & 94 & $27 \%$ \\
\hline Sophomore & 104 & $30 \%$ \\
\hline Junior & 76 & $22 \%$ \\
\hline Senior & 75 & $21 \%$ \\
\hline \multicolumn{3}{|l|}{ Years Playing Collegiately } \\
\hline First Year & 157 & $45 \%$ \\
\hline Second Year & 91 & $26 \%$ \\
\hline Third Year & 71 & $20 \%$ \\
\hline Fourth Year & 30 & $9 \%$ \\
\hline \multicolumn{3}{|l|}{ NCAA Division } \\
\hline Membership & 93 & $27 \%$ \\
\hline Division I & 120 & $34 \%$ \\
\hline $\begin{array}{l}\text { Division II } \\
\text { Division III }\end{array}$ & 136 & $39 \%$ \\
\hline \multicolumn{3}{|l|}{ Profile of Sport } \\
\hline High & 152 & $44 \%$ \\
\hline Low & 197 & $56 \%$ \\
\hline
\end{tabular}

Journal of Amateur Sport Volume Two, Issue Two

Moore, 2016 
Table 3

Availability of Support Services: Perceptions of Athletic Directors and Student-Athletes

\begin{tabular}{lll} 
Service & Athletic Director & $\begin{array}{l}\text { Student-Athlete } \\
M(S D)\end{array}$ \\
\hline Athletic Training & $7.61(0.75)$ & $6.81(1.59)$ \\
Tutoring Services & $6.94(1.44)$ & $6.38(2.04)$ \\
Academic Advising & $6.86(1.27)$ & $6.66(1.67)$ \\
Medical Services & $6.85(1.49)$ & $5.79(2.16)$ \\
Career Development & $6.25(1.71)$ & $5.93(2.08)$ \\
Mental Health Services & $5.65(1.87)$ & $4.42(2.38)$ \\
Substance Abuse & $5.49(1.80)$ & $4.29(2.33)$ \\
Services & & \\
Alcohol Addiction & $5.47(1.78)$ & \\
Services & & $3.28(2.34)$ \\
Suicide Prevention & $5.00(2.21)$ & \\
- Not & & \\
\hline
\end{tabular}

Note: Respondents were asked to indicate service availability on a nine-point scale $(0=$ Never to 8 $=$ All the Time) 
Table 4

Results for Service Availability (Athletic Directors)

\begin{tabular}{llll}
\hline Service Type & Division & $M(S D)$ & Post-hoc Results \\
\hdashline Athletic & I & $16.63(1.92)$ & \\
& II & $16.50(1.49)$ & \\
Academic & III & $16.28(2.45)$ & \\
& I & $23.82(2.97)$ & \\
Psychosocial $*$ & II & $22.69(3.84)$ & \\
& III & $22.78(4.13)$ & \\
& I & $22.79(6.24)$ & I $<$ III $(p=$ \\
& II & & \\
$* F_{(2,129)}=6.08, p=0.003, C_{95}=(24.28,26.62), \eta^{2}=0.09$ &
\end{tabular}

Journal of Amateur Sport $\quad$ Volume Two, Issue Two Moore, 2016 
Table 5

Results for Service Availability (Student-Athletes)

\begin{tabular}{llll}
\hline Service Type & Division & $M(S D)$ & Post-hoc Results \\
\hline Athletic $^{*}$ & I & $15.37(2.84)$ & $\begin{array}{l}\text { I }>\text { III }(p< \\
0.001)\end{array}$ \\
& II & $15.18(2.81)$ & $\begin{array}{l}\text { II }>\text { III }(p< \\
0.001)\end{array}$ \\
& III & $14.60(3.60)$ & \\
& I & $23.39(4.17)$ & I $>$ III $(p<$ \\
& II & $0.001)$
\end{tabular}

